Витол Ирина Сергеевна, канд. биол. наук, старший научный сотрудник, ВНИИЗ - филиал ФГБНУ «ФНЦ пищевых систем им. В.М. Горбатова» РАН. Россия.

Герасина Анна Юрьевна, аспирант, младший научный сотрудник, ВНИИЗ - филиал ФГБНУ «ФНЦ пищевых систем им. В.М. Горбатова» РАН. Россия.
127434, г. Москва, Дмитровское шоссе, д. 11.

Тел.: 89267090207; e-mail: vitolis@yandex.ru.

Ключевые слова: тритикале; зерно; биопотенииал; протеолитические ферменты; увлажнение; подсушивание.

\title{
PROTEOLYTIC ENZYMES OF GRAIN TRITYCLE AFTER HUMIDIFICATION AND DRYING
}

Vitol Irina Sergeevna, Candidate of Biological Sciences, Senior Researcher, All-Russian Scientific Research Institute of Grain and Products of Its Processing - branch «V.M. Gorbatov Federal Research Center for Food Systems» of the Russian Academy of Sciences. Russia.

Gerasina Anna Yuryevna, Younger Researcher, AllRussian Scientific Research Institute of Grain and Products of Its Processing - branch «V.M. Gorbatov Federal Research Center for Food Systems» of the Russian Academy of Sciences. Russia.

Keywords: triticale; corn; biopotential; proteolytic enzymes; humidification; drying.
It has been shown that neutral proteinases in the triticale grain are distributed unevenly: the activity of enzymes are concentrated in the embryo - their activity is 5.2-6.5 times higher than that of whole grain. It has been established that moistening of the grain leads to an increase in the activity of neutral proteinases - at a content wetness of $30 \%$ it is higher than the initial protein by $60-80 \%$ (for whole grains). In the embryo, the activity of the enzymes rapidly increases and, with a wetness content of $20 \%$, reaches a maximum, increasing 1.5-2.0 times. In a seed without an embryo, the activity of neutral proteinases at a humidity of $30 \%$ is $118 \%$ and $120 \%$ of the initial one. Drying of moistened grain is accompanied by a decrease in the activity of neutral proteinases, but remains higher (by 15-25\%) compared to grain with the initial moisture content.

DOI

УдК 634.324: 631.52

\section{КРИТЕРИИ ПОДБОРА КОМБИНАЦИЙ СКРЕЩИВАНИЯ ДЛЯ СОЗДАНИЯ ГИБРИДНОГО ФОНДА МАНДАРИНА (CITRUS RETICULATA BLAN. VAR. UNCHIU TAN.)}

\author{
кУЛЯН Раиса Васильевна, Всероссийский научно-исследовательский институт иветоводства \\ и субтропических культур
}

В селекиионной практике с иитрусовыми культурами для получения гибридных семян учитываются следующие основные принципы: признаковый, географический. Признаковый принцип (Citrus reticulata Blan. var. unchiu Tan.) позволяет основываться на использовании источников селекционно-значимых признаков урожайности, низкорослости, биотической и абиотической устойчивости, комплексном содержании компонентов биохимического состава; оценка исходных форм проводится по фенотипу. Географический принцип основан на применении межродовой и межвидовой гибридизации. Использование диких, полудиких и культурных сородичей ичтрусовых позволяет получать гибриды с больиим спектром изменчивости по важным признакам (раннеспелость, скороплодность, крупноплодность). Проанализиров 47 комбинаций скрещивания, выделена 21 перспективная для создания гибридного фонда мандарина, где материнские формы 'КошапоWase', 'Miyagawa Wase', 'Юбилейный' передают своему потомству низкорослость, раннеспелость, урожайность, качество плодов. Сородичи и гибридные виды иитрусовых С. $\times$ tangelo, C. $\times$ clementina, C. $\times$ leiocarpa, C. $\times$ insitorum, P. trifoliata, гибрид 3252 передают зимостойкость, крупноплодность. Самъми результативнъми комбинациями по въходу зимостойких сеянщев являются скрещивания 'Miyagawa Wase' $\times$ P. trifoliata, 'Kowano-Wase' $\times$ P. trifoliata и 'Kowano-Wase' $\times$ C. $\times$ insitorum. Наибольший выход низкорослых сеянцев отмечен в комбинациях с участием в качестве опылителя С. leiосагра. В комбинациях 'Юбилейный' $\times$ C. $\times$ insitoruт, 'Юбилейный' × гибрид 3252, 'Miyagawa Wase' $\times$ C. $\times$ insitorum выделено наибольщее количество раннеспелых форм. Крупноплодность передают потомству отиовские формы C. $\times$ insitorum, C. sinensis 'Valencia'.

Введение. Цитрусовые широко культивируют во многих субтропических и тропических областях земного шара, в странах Средиземноморья (Испания, Италия, Марокко и др.), на юге США (Калифорния, Флорида), в Бразилии, Аргентине, Японии, Китае, Индии, Пакистане, Индокитае, Австралии и ЮАР. Самыми распространенными цитрусовыми культурами являются апельсин, мандарин и лимон с их многочисленными сортами. В России цитрусовые выращивают в субтропической зоне Черноморского побережья, которая является самым северным в мире районом их возделывания. Промышленное значение здесь имеет мандарин [5].

Мандарин (Citrus reticulata Blan. var. unchiu Tan.) по вкусовым качествам превосходит все другие цитрусовые. Поэтому в последние годы наблюдается неуклонный рост производства мандаринов, в связи с чем именно в этой группе цитрусовых постоянно появляется наибольшее количество новых сортов и гибридных видов. Скрещивание C. reticulata c разными генотипами является основным методом получения новых сочетаний признаков.

При гибридизации, особенно отдаленной, можно получать новые формы, не похожие на исходные, и объединять в потомстве свойства и признаки родительских форм, иногда исправлять отдельные недостатки сорта. Подбор родительских пар, а также методы дальнейшей работы с гибридами, полученными в предыдущие годы, имеют большое значение и часто определяют успех селекционной 
работы $[1,2]$. В селекционной практике как с плодовыми, так и с цитрусовыми культурами для получения гибридных семян учитываются следующие принципы: признаковый, географический [6], генетический и молекулярно-биологический для определения филогенетических связей $[7,8]$.

В настоящее время цель исследований остается прежней - создание новых высокоурожайных, низкорослых, раннеспелых форм, наиболее приспособленных к экстремальным условиям выращивания.

Методика исследований. Исследования проводили на базе Всероссийского научно-исследовательского института цветоводства и субтропических культур. Объектом исследований являлся гибридный фонд, полученный в период 1995-2017 гг. Анализ гибридного материала проводили согласно общепринятым программам и методикам сортоизучения плодовых и субтропических культур [3, 4].

Результаты исследований. За период 19952017 гг. проведено 47 комбинаций скрещивания мандариновой группы, в результате получено 2650 гибридных и нуцеллярных сеянцев. По совокупности морфологических признаков, коррелирующих с зимостойкостью, низкорослостью, раннеспелостью, выделено 122 формы из них 44 перспективных.

Основным принципом в селекционной работе c C. reticulata является признаковый, где оценка исходных форм проводится по фенотипу. При подборе родительских компонентов главным критерием является наличие селектируемых признаков (урожайность, низкорослость, биотическая и абиотическая устойчивость, комплексное содержание компонентов биохимического состава). При этом другие признаки должны отвечать следующим требованиям: родительские формы не должны иметь одинаковые отрицательные признаки; одна из родительских форм должна обладать большим количеством положительных признаков.

При подборе родительских пар для скрещивания C. reticulata роль материнского компонента возлагается на формы с лучшими качествами, стерильные или с низкой жизнеспособностью пыльцы, так как материнское растение всегда полнее передает потомству свои свойства. Все отобранные отцовские формы, за исключением C. sinensis ‘Valencia', обладают устойчивостью к низким температурам и образуют фертильную, жизнеспособную пыльцу (см. таблицу).

Признаковый принцип отбора родительских форм важен тем, что позволяет основываться на использовании источников селекционно-значимых признаков.

Географический принцип в селекции C. reticulata имеет широкое применение, который основан на том, что эффективность селекционного процесса повышается, если в гибридном потомстве наблюдается большой спектр изменчивости по важным признакам. Прежде всего это связано с генетическими различиями между компонентами скрещивания, что обеспечивает максимальный уровень различий в потомстве. Ведущим методом создания новых форм C. reticulata является межви- довая гибридизация, которая позволяет вовлечь в селекционный процесс различные виды рода Citrus (C.junos var. juzu, C. $\times$ insitorum, C. tangerin, C. sinensis) с целью получения нового генетического материала. Метод межвидовой гибридизации эффективен при передаче отдельных признаков (крупноплодность, качество плодов, размер и форма плодов и листовой пластинки) от одного вида другому.

Отдаленная гибридизация с использованием диких (P. trifoliata), полудиких (C. ichangensis) и культурных сородичей цитрусовых (Fortunella, гибрид 3252, C. $\times$ leiocarpa, C. $\times$ tangelo) позволяет получать гибриды, устойчивые к биотическим и абиотическим стрессам.

При межродовых скрещиваниях учитывали получение второго и последующих поколений, так как только в некоторых случаях в гибридном потомстве $\mathrm{F}_{1}$ удается выделить генотип, который по комплексу признаков (зимостойкость, урожайность, качество плодов) удовлетворяет требованиям, предъявляемым техническим сортам. Главным образом это гибриды мандарина с Fortunella, C. × insitorum, гибрид 3252.

При повторном скрещивании гибриды $\mathrm{F}_{2}$ более жизнеспособны, плоды лучшего качества, однако нами отмечена меньшая устойчивость к низким температурам.

Проанализировав 47 проведенных комбинаций скрещивания, выделена 21 перспективная для создания гибридного фонда мандарина, где материнские формы 'Kowano-Wase', 'Miyagawa Wase', 'Юбилейный' передают своему потомству такие признаки, как низкорослость, раннеспелость, урожайность и качество плодов. Отцовские формы C. $\times$ tangelo, C. $\times$ clementina, C. $\times$ leiocar-

Селекционно-значимые признаки родительских форм мандарина

\begin{tabular}{|c|c|}
\hline Сорт & Признак \\
\hline \multicolumn{2}{|c|}{ Материнские формы } \\
\hline $\begin{array}{l}\text { ‘Kowano-Wase', 'Miyagawa Wase', } \\
\text { ‘Юбилейный', 'Иверия' } \\
\end{array}$ & Урожайность 220-250 ц/га \\
\hline $\begin{array}{l}\text { ‘Kowano-Wase','Miyagawa Wase’ } \\
\text { 'Юбилейный', 'Сентябрьский’' }\end{array}$ & $\begin{array}{l}\text { Сдержанный рост (до 3,0 м) } \\
\text { и компактность кроны }\end{array}$ \\
\hline $\begin{array}{l}\text { 'Kowano-Wase', 'Miyagawa Wase', } \\
\text { 'Юбилейный' }\end{array}$ & $\begin{array}{l}\text { Раннеспелость (сентябрь-- } \\
\text { октябрь) }\end{array}$ \\
\hline $\begin{array}{l}\text { ‘Kowano-Wase’, 'Miyagawa Wase’, } \\
\text { ‘Юбилейный’, 'Сентябрьский’, } \\
\text { ‘Миллениум’ }\end{array}$ & $\begin{array}{l}\text { Качество плодов: масса плода } \\
59-90 \text { г и выше. Соотношение } \\
\text { сахаров к кислоте - 6,0-8,5\%; } \\
\text { витамин С - } 30-35 \text { мг\% }\end{array}$ \\
\hline ‘Черноморский’, ‘Иверия’ & $\begin{array}{l}\text { Устойчивость к низким } \\
\text { температурам }\left(-6 \ldots-8{ }^{\circ} \mathrm{C}\right)\end{array}$ \\
\hline \multicolumn{2}{|c|}{ Отцовские формы } \\
\hline $\begin{array}{l}\text { Fortunella, C. } \times \text { leiocarpa, } \text { C. } \times \text { tangelo, } \text { C. } \times \\
\times \text { insitorum, }, \text { C. } \times \text { tangerin, } \text { C. sinensis 'Valencia' }\end{array}$ & Урожайность (120-150 ц/га) \\
\hline C. junos var. juzu, Fortunella & $\begin{array}{l}\text { Сдержанный рост (до 3,0 м) } \\
\text { и компактность кроны }\end{array}$ \\
\hline $\begin{array}{l}\text { C. junos var. juzu, C. } \times \text { leiocarpa, } \\
\text { C. } \times \text { tangelo }\end{array}$ & $\begin{array}{l}\text { Раннеспелость (сентябрь- } \\
\text { октябрь), скороплодность }\end{array}$ \\
\hline $\begin{array}{l}\text { C. junos var. juzu, C. } \times \text { insitorum, } \\
\text { C. tangerin, C. sinensis 'Valencia' }\end{array}$ & $\begin{array}{l}\text { Качество плодов: масса плода } \\
59-90 \text { г и выше. Соотношение } \\
\text { сахаров к кислоте - 6,0-8,5\%; } \\
\text { витамин С - } 30-55 \text { мг\% }\end{array}$ \\
\hline Гибрид $3252 *$, C. leiocarpa & $\begin{array}{l}\text { Устойчивость к низким } \\
\text { температурам }\left(-8 \ldots-10^{\circ} \mathrm{C}\right)\end{array}$ \\
\hline $\begin{array}{l}\text { P. trifoliata, C. ichangensis, Fortunella, } \\
\text { C. } \times \text { insitorum, C. junos var. juzu }\end{array}$ & $\begin{array}{l}\text { Устойчивость к низким } \\
\text { температурам }\left(-10 \ldots-15^{\circ} \mathrm{C}\right)\end{array}$ \\
\hline Все формы & $\begin{array}{l}\text { Высокая жизнеспособность, } \\
\text { фертильность пыльцы }\end{array}$ \\
\hline
\end{tabular}

* получен Ф.М. Зориным, включает в себя генотипы мандарина C. unshiu, P. trifoliata, C. × leiocarpa 
pa, C. $\times$ insitorum, P. trifoliata, гибрид 3252 - зимостойкость, крупноплодность (см. рисунок).

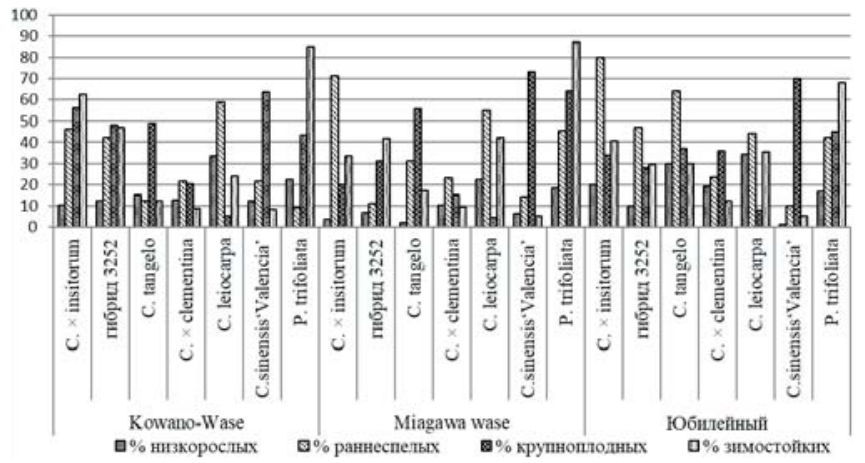

Эффективность отбора сеянщев по комплексу ценных признаков, \%

По итогам комплексной оценки гибридного потомства в изучаемых комбинациях были выделены и отобраны сеянцы, сочетающие хозяйственно-ценные признаки. Самыми результативными комбинациями по выходу зимостойких сеянцев являются 'Miyagawa Wase' $\times$ P. trifoliata и 'KowanoWase' $\times$ P. trifoliata и 'Kowano-Wase' $\times C$. $\times$ insitorum. Полученные на их основе формы представляют качественно новый в генетическом отношении исходный материал для дальнейшей селекции.

Наибольший выход низкорослых сеянцев отмечали в комбинациях с участием в качестве опылителя C. leiocarpa. В комбинациях 'Юбилейный $\times$ C. $\times$ insitorum, 'Юбилейный' $\times$ гибрид 3252, 'Miyagawa Wase' $\times$ C. $\times$ insitorum выделено наибольшее количество раннеспелых форм. Крупноплодность передают потомству отцовские формы C. × insitorum, C. sinensis 'Valencia'.

Отцовские формы C. $\times$ tangelo, C. $\times$ clementina, C. leiocarpa и межродовой гибрид 3252 обеспечивают в потомстве доминирование признаков культурного вида и являются наиболее перспективными для получения форм с хозяйственноценными признаками для дальнейшей селекции.

Заключение. Для создания гибридного фонда мандарина выделены самые результативные комбинации скрещивания: на зимостойкость - 'Miyagawa
Wase' $\times$ P. trifoliata; 'Kowano-Wase' $\times P$. trifoliata; 'Kowano-Wase' $\times$ C. $\times$ insitorum; на раннеспелость 'Юбилейный' $\times$ C. $\times$ insitorum; 'Юбилейный' × гибрид 3252; 'Miyagawa Wase' $\times$ C. $\times$ insitorum; на крупноплодность и зимостойкость - 'Miyagawa Wase' $\times$ C. sinensis 'Valencia'.

\section{СПИСОК ЛИТЕРАТУРЫ}

1. Кулян Р.В. Селекция цитрусовых (мандарин) в условиях субтропической зоны Краснодарского края // Садоводство и виноградарство. - 2013. - № 2. - С. 11-16.

2. Кулян Р.В. Создание сортов цитрусовых на юге России // Субтропическое и декоративное садоводство: сб. науч. тр. - Сочи: ВНИИЦиСК, 2007. - Т. 40. - С. 221-231.

3. Программа и методика сортоизучения плодовых, ягодных и орехоплодных культур / под ред. Е.Н. Седова, Т.П. Огольцовой. - Орел: ВНИИСПК, 1999. - 608 с.

4. Программа Северо-Кавказского центра по селекции плодовых, ягодных, цветочно-декоративных культур и винограда на период до 2030 г. - Краснодар: ГНУ СКЗНИИСиВ, 2013. - 202 с.

5. Рындин А.В., Кулян Р.В. Возможности повышения зимостойкости цитрусовых во влажных субтропиках России // Плодоводство и ягодоводство России. - 2013. - Т. XXXVII. - № 2. - С. 204-207.

6. Ускорение и повышение эффективности селекции плодовых культур / Г.В. Еремин [и др.]. - Краснодар, 2010. - 55 с.

7. Li Y.Z., Cheng Y.J., Yi H.L., Deng X.X. Genetic diversity in mandarin landraces and wild mandarins from China based on nuclear and chloroplast simple sequence repeat markers // J. Hort. Sci. Biotechnol., 2006, 81:371-378.

8. Siragusa M., Pasquale F., Abbate L., Tusa N. Identification of sour orange accessions and evaluation of their genetic variability by molecular marker analysis // Hortic. Sci., 2006, 41: 84-89.

Кулян Раиса Васильевна, канд. с.-х. наук, зав. лабораторией селекиии плодовых культур отдела субтропических и южных плодовых культур, Всероссийский научно-исследовательский институт изетоводства и субтропических культур. Россия.

354002, г. Сочи, ул. Яна Фабрициуса, 2/28.

Тел.: (862) 246-80-16.

Ключевые слова: иитрусовые; мандарин; гибридизация; результативность скрещивания; гибридный фонд.

\section{CRITERIA SELECTION COMBINATIONS OF CROSSING FOR CREATION TANGERINE HYBRID FUND (CITRUS RETICULATA BLAN. VAR. UNCHIU TAN.)}

Kulyan Raisa Vasilievna, Candidate of Agricultural Sciences, Head of the fruit crops laboratory, Federal State Budgetary Scientific Institution "Russian Research Institute of Floriculture and Subtropical Crops”. Russia.

Keywords: citrus plants; tangerine; hybridization; productivity of crossing; hybrid fund.

The combination of various directions in selection provides creation of varieties with a complex of properties and the signs possessing high productivity adapted to certain soil, climatic and economic conditions. In selection practice with citrus fruit crops for reception of hybrid seeds following main principles are considered: characterical, geographical. Characterical a principle in selection work with tangerine (Citrus reticulata Blan. var. unchiu Tan.) Allows to be based on use of sources selection-significant signs - productivity, low-growing, biotical and abiotical stability, the complex maintenance components of biochemical structure, the estimation of initial forms is spent on phenotype. Geographical principle in tangerine selection has wide application it is based on application of interpatrimonial and interspecific hybridization. Use of wild, half-civilized and cultural relatives of citrus allows to receive hybrids with the big spectrum of variability to the important signs (early naturity, fast maturing of fruits, large fruits). 47 combinations of crossing were analyzed and allocated 21 - perspective for creation of hybrid fund of a tangerine where parent forms "Kowano-Wase", "Miyagawa Wase", "Yubileinii" - transfer to the posterity such signs as - low-growing, early naturity, productivity, quality of fruits. Relatives and hybrid kinds of citrus $C$. $\times$ tangelo, $C \times$ clementina, C. $\times$ leiocarpa, C. $\times$ insitorum, P. trifoliata, hybrid 3252 transfer winter hardiness, large fruits. The most productive combinations on an exit winter-hardy seedlings are crossings "Miyagawa Wase" $\times$ P. trifoliata, "Kowano-Wase" $\times$ P. trifoliata and "Kowano-Wase" $\times$ C. $\times$ insitorum. The greatest exit of undersized seedlings is noted in combinations with participation in quality pollinator C. leiocarpa. In combinations "Yubileinii" $\times$ C. $\times$ insitorum, "Yubileinii" $\times$ hybrid 3252, "Miyagawa Wase" $\times$ C. $\times$ insitorum the greatest quantity early naturity forms is allocated. Large fruits are transfer to posterity fatherly forms $C . \times$ insitorum, C sinensis "Valencia"'. 